\title{
ANALISA KEBUTUHAN AIR BERSIH (STUDI KASUS DESA SIMPANG GAUNG KECAMATAN GAUNG KABUPATEN INDRAGIRI HILIR)
}

\author{
Wiro Saputra ${ }^{1}$ \\ ${ }^{1}$ Program Studi Teknik Sipil Universitas Islam Indragiri, Tembilahan \\ Email: wiro_saputra_unisi@gmail.com (korespondensi)
}

\begin{abstract}
Water is a basic need for human survival, the need of clean water continue to increase while the supply of raw water infrastructure is still limited, there is often a lack of fulfillment of needs during the dry season, clean water crisis is one of the problems in Indragiri Hilir District especially in Simpang Gaung Village. Planning for a clean water distribution system really needs to be taken into account in order to guarantee the fulfillment of the level of service, in planning the clean water pipeline is determined by the water requirements and the required flow pressure. The amount or discharge of water provided depends on the population and industry served. The purpose of this study is to obtain clean water needs and a piping network system 15 based on the needs of the population in the next 15 years. The population of Simpang Gaung Village in 2018 is 4,100 people, with the semi average soul method of population growth up to 2033 is 4,283 people. The total water demand with a population of 4334 million in 2033 is 2.9420 liters / second. The source of water used is the river.
\end{abstract}

Keywords: Clean Water Needs, Distribution system

\begin{abstract}
Abstrak
Air merupakan kebutuhan yang mendasar bagi kelangsungan hidup manusia, kebutuhan air bersih terus meningkat sementara penyediaan prasarana air baku masih terbatas, sering terjadi kekurangan pemenuhan kebutuhan saat musim kemarau, krisis air bersih merupakan salah satu masalah di Kabupaten Indragiri Hilir khusunya di Desa Simpang Gaung. Perencanaan sistem distribusi air bersih sangat perlu diperhitungkan agar dapat menjamin terpenuhinya tingkat pelayanan, pada perencanaan jaringan pipa air bersih ditentukan oleh kebutuhan air dan tekanan aliran yang diperlukan. Jumlah atau debit air yang disediakan tergantung pada jumlah penduduk dan industri yang dilayani. Tujuan dari studi ini adalah untuk mendapatkan kebutuhan air bersih dan sistim jaringan perpipaan 15 berdasarkan kebutuhan penduduk 15 tahun kedepannya. Jumlah penduduk Desa Simpang Gaung tahun 2018 berjumlah 4.100 jiwa, dengan metode semi average jiwa pertumbuhan penduduk sampai dengan tahun 2033 adalah 4.283 jiwa. Total kebutuhan air dengan jumlah penduduk 4334 juta jiwa pada tahun 2033 adalah 2,9420 liter/detik. Sumber air yang digunakan adalah sungai.
\end{abstract}

Kata kunci: Kebutuhan Air Bersih, sistem Distribusi

\section{Pendahuluan}

Air bersih adalah salah satu jenis sumber daya berbasis air yang bermutu baik dan biasa dimanfaatkan oleh manusia untuk dikonsumsi atau dalam melakukan aktivitas sehari hari. Air bersih merupakan bagian penting dalam kehidupan manusia, sehingga ketersediaan air bersih sangat berpengaruh bagi kehidupan manusia. Pengaruh dari ketersediaan air bersih tidak hanya pada kebutuhan rumah tangga, tetapi berpengaruh pada sektor sosial, ekonomi, maupun fasilitas umum, seiring dengan peningkatan pertumbuhan penduduk.

Kebutuhan air bersih merupakan kebutuhan yang tidak terbatas dan berkelanjutan. Peningkatan kebutuhan ini disebabkan oleh peningkatan jumlah penduduk, peningkatan derajat kehidupan warga serta perkembangan kota / kawasan pelayanan ataupun hal yang berhubungan dengan peningkatan kondisi sosial dan ekonomi warga.

Kepadatan penduduk berkaitan erat 
dengan peningkatan pertumbuhan penduduk dan mempengaruhi aktivitas, perkembangan dalam segi sosial, ekonomi, serta pengembangan fasilitas umum, sehingga tingkat kebutuhan air bersih akan meningkat pula.meningkatnya jumlah penduduk tiap tahun yang semakin tinggi, maka kebutuhan air bersih juga meningkat, adapun sebagian besar penyediaan air bersih diwilayah ini bersumber dari mata air tanah dalam, air tanah dangkal dan air permukaan yang merupakan milik pribadi, hal ini terjadi karena tidak tersedianya jaringan sistem perpipaan di desa.

Mengingat pentingnya peranan air bersih bagi keberlangsungan hidup manusia serta adanya permasalahan-permasalahan dalam pemenuhan kebutuhan air bersih, maka diadakan suatu analisis kebutuhan penduduk akan air bersih mengenai jaringan distribusi penyediaan air bersih untuk beberapa tahun kedepan.

\section{TINJAUAN PUSTAKA}

\subsection{Kebutuhan Air}

Langkah awal dalam suatu perencanaan penyediaan air bersih adalah memperkirakan jumlah kebutuhan air. Sulit untuk mendapatkan angka yang pasti jumlah pemakaian air suatu daerah, karena banyak faktor yang mempengaruhinya. Pendekatan yang dapat dilakukan adalah menghitung rata-rata pemakaian setiap orang perhari, memperkirakan jumlah penduduk pada jangka waktu tertentu dan umur rencana konstruksi.

Data masa lalu tentang suatu daerah merupakan petunjuk yang baik dalam pemilihan suatu angka tentang penggunaan air perkapita bagi tujuan-tujuan perencanaan, disamping itu data-data mengenai jumlah penduduk sangat membantu memperkirakan jumlah penduduk pada jangka waktu tertentu

\subsubsection{Kebutuhan Air Dosmetik}

Kebutuhan air domestik adalah kebutuhan air yang digunakan pada tempattempat hunian pribadi untuk memenuhi keperluan sehari-hari seperti memasak, minum, mencuci dan keperluan rumah tangga lainnya. Satuan yang dipakai adalah liter /orang / hari, kriteria perencanaan air bersih dapat dilihat pada Tabel Berikut :
Tabel 1. Kebutuhan Air Domestik

\begin{tabular}{|c|c|c|c|c|c|c|}
\hline \multirow{3}{*}{ No } & \multirow{3}{*}{ Uraian } & \multicolumn{5}{|c|}{$\begin{array}{l}\text { Kategori Kota Berdas arkan Jumlah } \\
\text { Penduduk ( Jiwa ) }\end{array}$} \\
\hline & & 1.000 .000 & $\begin{array}{l}500.000 \\
1.000 .000\end{array}$ & $\begin{array}{l}100.000 \\
500.000\end{array}$ & $\begin{array}{l}20.000 \\
100.000\end{array}$ & $<20.000$ \\
\hline & & Metro & Besar & Sedang & Kecil & Desa \\
\hline 1 & $\begin{array}{l}\text { Konsumsi Unit } \\
\text { Sambungan Rumah } \\
\text { (SR)Vorghari }\end{array}$ & 190 & 170 & 150 & 130 & 30 \\
\hline 2 & $\begin{array}{l}\text { Konsumsi Unit Hidran } \\
\text { Umum (HU) Vorg/hri }\end{array}$ & 30 & 30 & 30 & 30 & 30 \\
\hline 3 & $\begin{array}{l}\text { Konsumsi UnitNon } \\
\text { Domestik (\%) }\end{array}$ & $20-30$ & $20-30$ & $20-30$ & $20-30$ & $10-20$ \\
\hline \begin{tabular}{|l|}
4 \\
\end{tabular} & Kehilangan Air (\%) & $20-30$ & $20-30$ & $20-30$ & $20-30$ & 20 \\
\hline 5 & $\begin{array}{l}\text { Faktor Maksimum } \\
\text { Perhari }\end{array}$ & 1,1 & 1,1 & 1,1 & 1,1 & 1,1 \\
\hline 6 & $\begin{array}{l}\text { Faktor Pada Jam } \\
\text { Puncak }\end{array}$ & 1,5 & 1,5 & 1,5 & 1,5 & 1,5 \\
\hline \begin{tabular}{|l|}
7 \\
\end{tabular} & Jumlah Jiwa Per SR & 5 & 5 & 6 & 6 & 10 \\
\hline 8 & Jumlah Jiwa Per HU & 100 & 100 & 100 & $100-200$ & 200 \\
\hline 9 & $\begin{array}{l}\text { Sisa tekan di Jaringan } \\
\text { Distribusi (meter) }\end{array}$ & 10 & 10 & 10 & 10 & 10 \\
\hline 10 & Jam Operasi (jam) & 24 & 24 & 24 & 24 & 24 \\
\hline 11 & Volume Reservoir (\%) & 20 & 20 & 20 & 20 & 20 \\
\hline 12 & SR: $\mathrm{HU}$ & $\begin{array}{c}50: 50 \\
\mathrm{~s} / \mathrm{d} 80: 20\end{array}$ & $\begin{array}{c}50: 50 \\
s / d 80: 20\end{array}$ & $80: 20$ & $70: 30$ & $70: 30$ \\
\hline 13 & Cakupan Pelayanan (\%) & 90 & 90 & 90 & 90 & 70 \\
\hline
\end{tabular}

\subsubsection{Kebutuhan Air Non Domestik}

Kebutuhan air non domestik adalah kebutuhan air bersih diluar keperluan rumah tangga. Kebutuhan air non domestik antara lain Penggunaan komersil dan industri yaitu penggunaan air oleh badan-badan komersil dan industri.Penggunaan umum yaitu penggunaan air untuk bangunan-bangunan pemerintah, rumah sakit, sekolah-sekolah dan tempat-tempat ibadah. Kebutuhan ini bisa mencapai antara $20 \%$ - $25 \%$ dari total kebutuhan air domestik.

\subsubsection{Fluktuasi Kebutuhan Air}

Kebutuhan air bergantung pada musim,musim kemarau kebutuhan air untuk menyiram tanaman, mandi, cuci, dan minuman meningkat. Menurut Direktorat Jenderal Cipta Karya, kebutuhan maksimum harian adalah $38 \%$ lebih tinggi dari kebutuhan rata-rata.

Tabel 2. Pemakaian Air Tiap Jam

\begin{tabular}{|l|l|l|l|l|l|}
\hline $\begin{array}{l}\text { Ja } \\
\mathrm{m}\end{array}$ & $\begin{array}{l}\text { Koefisie } \\
\mathrm{n}\end{array}$ & $\begin{array}{l}\mathrm{Ja} \\
\mathrm{m}\end{array}$ & $\begin{array}{l}\text { Koefisie } \\
\mathrm{n}\end{array}$ & $\begin{array}{l}\text { Ja } \\
\mathrm{m}\end{array}$ & $\begin{array}{l}\text { Koefisie } \\
\mathrm{n}\end{array}$ \\
\hline 1 & 0 & 9 & 0.86 & 17 & 2.29 \\
\hline 2 & 0 & 10 & 1.14 & 18 & 1.14 \\
\hline 3 & 0.29 & 11 & 1.43 & 19 & 1.14 \\
\hline 4 & 0.57 & 12 & 1.43 & 20 & 0.86 \\
\hline 5 & 1.14 & 13 & 1.71 & 21 & 0.57 \\
\hline 6 & 1.71 & 14 & 1.43 & 22 & 0.57 \\
\hline 7 & 2 & 15 & 0.86 & 23 & 0 \\
\hline 8 & 1.14 & 16 & 1.71 & 24 & 0 \\
\hline
\end{tabular}

(Sumber : Triatmodjo, 2016) 
Kebutuhan air berfluktasi secara harian, Kebutuhan air meningkat mulai pukul 4.00 pagi dan mencapai puncak pada sekitar pukul 06.00 pagi, aktivitas warga untuk mandi, cuci, dan bersih-bersih meningkat. Pukul 07.00 pagi sebagian masyarakat sudah mulai meninggilkan rumah untuk bekerja atau kegiatan lainnya. Aktivitas setelah itu tidak terlalu banyak membutuhkan air sehingga kebutuhan pada pukul 8 hingga 4 sore biasanya tidak terlalu tinggi. Selanjutnya pukul 4 sore mulai beraktivitas melakukan bersih-bersih dan mandi sehingga kebutuhan air kembali meningkat. Sore hari waktu melakukan kegiatam lebih tersebar, yaitu pada pukul 16.00 sampai dengan pukul 19.00.(Triatmadja, 2016).

\subsection{Sistem Distribusi}

Menurut Sarwoko M, (1985) dalam siahaya is mayosa 2010, Mendistribusikan air bersih pada dasarnya dapat dipakai salah satu sistem diantara tiga sistem pengaliran, yaitu:

\subsubsection{Sistem Pengaliran Gravitasi}

Sistem ini digunakan bila elevasi sumber air baku atau pengolahan berada jauh diatas elevasi daerah layanan dan sistem ini dapat memberikan energi potensial yang cukup tinggi sehingga pada daerah layanan yang paling menguntungkan karena pengoperasian dan pemeliharaannya lebih murah.

\subsubsection{Sistem Pemompaan}

Sistem ini digunakan bila elevasi antara sumber air atau instalasi dan daerah pelayanan tidak dapat memberikan tekanan air yang cukup, Untuk debit dan tekanan yang diinginkan, air akan langsung ke jaring pipa distribusi. Sistem ini biasanya diterapkan pada daerah yang perbedaan elevasinya kecil.

\subsubsection{Sistem Pengolahan Pengaliran Kombinasi}

Sistem ini merupakan pengaliran dimana air bersih dari sumber atau instalasi pengolahan akan dialirkan ke jaringan dengan menggunakan pompa dan reservoir distribusi baik dioprasikan secara berganti atau bersama-sama. Reservoir ini berfungsi menampung air pada saat kebutuhan air minimum dan mendistribusikannya pada sa'at dibutuhkan (biasanya pada saat kebutuhan air maksimum). Tinggi reservoir yang cukup akan dapat menambah tinggi tekan.

\subsubsection{Sistem Air Disuplai Melalui Pipa Induk}

Kebutuhan air bersih masyarakat dapat menggunakan sistim yang disuplay pipa induk.

\subsection{Sistem Jaringan Distribusi}

Jaringan distribusi berfungsi untuk mengalirakan air dari unit produksi ke pelanggan. Jaringan distribusi menggunakan pipa dengan aliran bertekanan, dimana sepanjang perpipaannya dihubungkan dengan sambungan pelanggan. Jenis sambungan pelanggan dapat berupa Sambungan Rumah (SR), Sambungan Umum (SU) maupun sambungan untuk pelanggan usaha komersil. Sistem perpipaan dapat ditemukan pada hampir semua jenis industri, dari sistem pipa tunggal yang sederhana sampai sistem pipa bercabang yang sangat kompleks.

\subsubsection{Sistem Pipa Tunggal}

Sistem pipa tunggal merupakan sistem perpipaan yang hanya menggunakan satu buah pipa tanpa menggunakan sambungan. Penurunan tekanan pada sistem pipa tunggal adalah merupakan fungsi dari laju aliran, perubahan ketinggian dan total head loss merupakan fungsi dari faktor gesekan, perubahan penampang. Aliran yang tidak mampu mampat, sifat fluida diasumsikan tetap pada saat sistem telah ditentukan, maka konfigurasi sistem, kekasaran permukaan pipa, perubahan elevasi, dan kekentalan fluida bukan lagi merupakan variabel bebas

\subsubsection{Sistem Pipa Majemuk}

Kebanyakan sistem perpipaan adalah sistem pipa majemuk, yaitu rangkaian pipa seri, paralel maupun berupa jaringan perpipaan.Mengunakan rangkaian pipa seri maupun paralel, penyelesaiaannya adalah serupa dengan perhitungan tegangan dan tahanan pada hukum ohm.Penurunan tekanan dan laju aliran identik dengan tegangan dan arus pada listrik. Namun persamaannya tidak identik dengan hukum ohm, karena penurunan tekanan sebanding dengan kuadrat dari laju aliran. Semua sistem pipa majemuk lebih mudah diselesaikan dengan persamaan empiris. Ada beberapa contoh sistem pipa majemuk, dengan memenuhi kaidah-kaidah tertentu sebagai berikut :

1. Sistem pipa yang disusun secara seri

Dua buah pipa atau lebih dipasang secara seri, semua pipa akan dilewati oleh aliran yang sama dan total rugi head pada 
seluruh sistem adalah jumlah kerugian pada setiap pipa dan perlengkapan pipa.

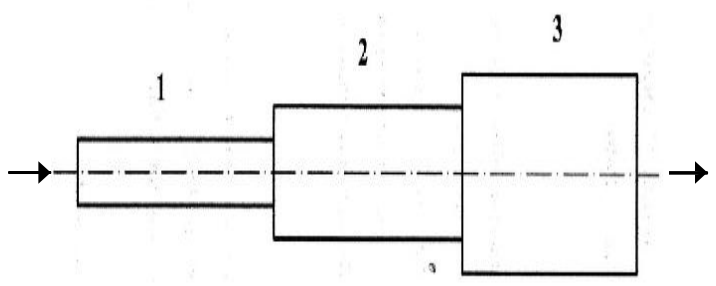

Gambar 1. Sistem Pipa yang disusun secara seri

Sumebr: FrankM. White (1988)

2. Sistem pipa yang disusun secara paralel Dua buah pipa atau lebih dipasang secara paralel, total laju aliran sama dengan jumlah laju aliran yang melalui setiap cabang dan kerugian head pada sebuah cabang sama dengan kerugian head pada cabang yang lain (Olson R.,1993).

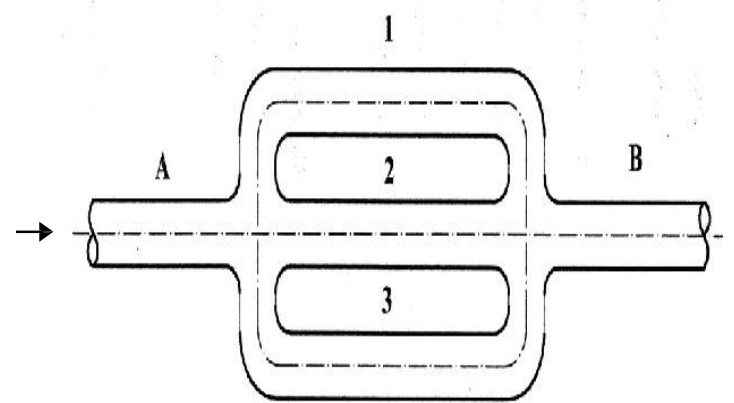

Gambar 2. Sistem Pipa yang disusun secara pararel

Sumber : Frank M. White (1988)

3. Jaringan Pipa

Jaringan ini merupakan saluran air untuk sebuah rumah tangga, suatu kompleks perumahan atau bahkan sebuah kota.

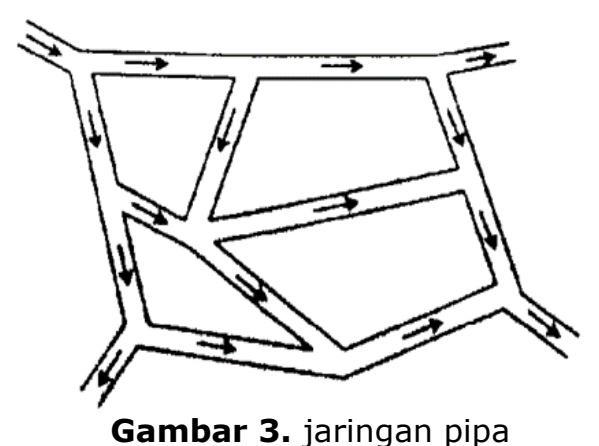

Sumber : White, 1986

\section{METODE PENELITIAN}

Analisis data yang telah didapat, maka digunakan analisis kebutuhan air dari suatu penduduk dan analisis sistim jaringan distribusi yang dapat mencukupi kebutuhan air tersebut.

\subsection{Metode Analisis Kebutuhan Air Bersih}

Metode Analisis Kebutuhan Air Bersih diterangkan bagaimana mencari kebutuhan air dalam suatu wilayah bilamana sudah mendapatkan data penduduk dalam suatu wilayah. Pertama dihitung pertumbuhan penduduk menggunakan standart perencanaan yang ditetapkan oleh Ditjen Cipta Karya Departemen Pekerjaan Umum, maka dapat dihitung pula jumlah kebutuhan air untuk penduduk pada tahun ini atau pada 10 tahun yang akan datang.

\subsection{Metode Analisis Sistim Jaringan Pipa Distribusi}

Analisis sistim jaringan pipa distribusi ini dapat dihitung setelah mendapatkan datadata yang berhubungan dengan letak sumber air, Debit kebutuhan air bersih dan data daerah layanan, dari data data yang diperoleh selanjutkan menggambarkan sketsa / peta daerah layanan dan menentukan dimensi pipa yang dibutuhkan berdasarkan bantuan program epanet.

\section{HASIL PENELITIAN}

\subsection{Proyeksi Pertumbuhan Penduduk}

Proyeksi Pertumbuhan Penduduk Desa Simpang Gaung Kec Gaung dihitung berdasarkan tingkat pertumbuhan penduduk 5 tahun terakhir dengan menggunakan metode semi average, Rasio pertumbuhan tersebut kemudian digunakan untuk dapat memproyeksikan pertumbuhan penduduk 15 tahun ke depan.

Tabel 3. Jumlah Penduduk 5 Tahun Terakhir Desa Simpang Gaung

\begin{tabular}{|l|l|l|}
\hline No. & Tahun & $\begin{array}{l}\text { Jumlah Penduduk } \\
\text { (jiwa) }\end{array}$ \\
\hline 1. & 2014 & 6.165 \\
\hline 2. & 2015 & 6.175 \\
\hline 3. & 2016 & 6.190 \\
\hline 4. & 2017 & 6.210 \\
\hline 5. & 2018 & 6.228 \\
\hline
\end{tabular}

Sumber :Data Olahan

Perhitungan proyeksi penduduk dilakukan dengan 3 metode, yaitu metode aritmatik, metode geometrik, dan metode eksponensial. Setelah diketahui hasil perhitungan masing-masing metode, maka dihitung standar deviasi dan koefisien korelasinya. Penentuan metode proyeksi penduduk yang dipilih berdasarkan 
nilai standar deviasi yang terkecil dan koefisien korelasi terbesar

Tabel 4. Persentase Laju Pertumbuhan Penduduk

\begin{tabular}{|l|l|l|l|l|}
\hline \multirow{2}{*}{ No. } & \multirow{2}{*}{ Tahun } & \multirow{2}{*}{$\begin{array}{l}\text { Jumlah } \\
\text { Penduduk } \\
\text { (jiwa) }\end{array}$} & \multicolumn{2}{|l|}{$\begin{array}{l}\text { Pertumbuhan } \\
\text { Pertahun }\end{array}$} \\
\cline { 4 - 5 } & & jiwa & \% \\
\hline 1. & 2014 & 6.165 & 15 & 0,0024 \\
\hline 2. & 2015 & 6.175 & 10 & 0,0016 \\
\hline 3. & 2016 & 6.190 & 15 & 0,0024 \\
\hline 4. & 2017 & 6.210 & 20 & 0,0032 \\
\hline 5. & 2018 & 6.228 & 18 & 0,0029 \\
\hline \multicolumn{2}{|l}{$\begin{array}{l}\text { Jumlah } \\
\text { Rata-rata }\end{array}$} & $\begin{array}{l}78 \\
15,6\end{array}$ & $\begin{array}{l}1,26 \% \\
0,25 \%\end{array}$ \\
\hline
\end{tabular}

Sumber : Data Olahan

\subsection{Proyeksi}

Penduduk

Metode

Hasil proyeksi jumlah penduduk desa simpang gaung dengan cara perhitungan Eksponensial hingga tahun 2033 disajikan pada Tabel Dibawah Ini:

Tabel 5. Rekapitulasi Perhitungan

\begin{tabular}{|c|c|c|c|c|c|}
\hline \multirow{2}{*}{ No. } & \multirow{2}{*}{ Tahun } & \multicolumn{3}{|c|}{ Jumlah Penduduk (jiwa) } & $\begin{array}{c}\text { Proyeksi } \\
\text { Rata2 (Jiwa) }\end{array}$ \\
\cline { 3 - 5 } & & Aritmatik & Geometrik & Eksponensial & 4100 \\
\hline 0. & 2018 & 4100 & 4100 & 4100 & 4112 \\
\hline 1. & 2019 & 4116 & 4110 & 4110 & 4124 \\
\hline 2. & 2020 & 4131 & 4121 & 4121 & 4136 \\
\hline 3. & 2021 & 4147 & 4131 & 4131 & 4149 \\
\hline 4. & 2022 & 4162 & 4142 & 4142 & 4161 \\
\hline 5. & 2023 & 4178 & 4152 & 4152 & 4173 \\
\hline 6. & 2024 & 4194 & 4163 & 4163 & 4185 \\
\hline 7. & 2025 & 4209 & 4173 & 4173 & 4197 \\
\hline 8. & 2026 & 4225 & 4184 & 4184 & 4210 \\
\hline 9. & 2027 & 4240 & 4194 & 4194 & 4222 \\
\hline 10 & 2028 & 4256 & 4205 & 4205 & 4234 \\
\hline 11. & 2029 & 4272 & 4215 & 4215 & 4246 \\
\hline 12. & 2030 & 4287 & 4226 & 4226 & 4259 \\
\hline 13. & 2031 & 4303 & 4237 & 4237 & 4271 \\
\hline 14. & 2032 & 4318 & 4247 & 4247 & 4283 \\
\hline 15 & 2033 & 4334 & 4258 & 4258 & \\
\hline \multicolumn{2}{|l|}{ Sumber Hasil Perhitungan } & & & \\
\hline
\end{tabular}

\subsection{Kebutuhan Air Domestik}

Pada awal tahun perencanaan yaitu pada tahun 2018 presentasi pelayanan direncanakan sebesar $100 \%$. Pelayanan jenis sambungan langsung pada awal perencanaan direncanakan $70 \%$ dan direncanakan presentasi pelayanannya ditingkatkan menjadi 90\% pada tahun 2023 dan $100 \%$ pada tahun selanjutnya, dengan kebutuhan air sebesar 90 L/o/dtk. Sedangkan untuk hidran umum pada awal perencanaan direcanakan $30 \%$ dan diharapakan turun menjadi $10 \%$ pada tahun 2023 dengan kebutuhan air 30 L/o/dt.

Tabel 6. Cakupan Pelayanan Untuk Kebutuhan Domestik 2018 -2033

\begin{tabular}{|c|c|c|c|c|c|c|c|}
\hline \multirow{2}{*}{ Tahun } & \multirow{2}{*}{ Jumlah Penduduk } & \multicolumn{2}{|c|}{ Cakupan Pelayanan } & \multicolumn{2}{|c|}{ S R } & \multicolumn{2}{c|}{ HU } \\
\cline { 3 - 8 } & & $\%$ & (Jiwa) & $\%$ & (Jiwa) & $\%$ & Jiwa \\
\hline 2018 & 4100 & 100 & 4100 & 70 & 2870 & 30 & 1230 \\
\hline 2023 & 4161 & 100 & 4161 & 90 & 3745 & 10 & 416 \\
\hline 2028 & 4222 & 100 & 4222 & 100 & 4222 & 0 & 0 \\
\hline 2033 & 4283 & 100 & 4283 & 100 & 4283 & 0 & 0 \\
\hline
\end{tabular}

sumber Hasi Perhitungan

Tabel 7. Kebutuhan Air Untuk Sambungan Rumah $2018-2033$

\begin{tabular}{|c|c|c|c|}
\hline \multirow{2}{*}{ Tahun } & $\begin{array}{c}\text { Jumlah } \\
\text { Penduduk }\end{array}$ & $\begin{array}{c}\text { Standar } \\
\text { Pemakaia }\end{array}$ & Kebutuhan Air \\
\cline { 2 - 4 } & Terlayani (Jiwa) & (L/o/hari) & (L/Hari) \\
\hline 2018 & 2870 & 90 & 258.300 \\
\hline 2023 & 3744,9 & 90 & 337.041 \\
\hline 2028 & 4222 & 90 & 379.980 \\
\hline 2033 & 4283 & 90 & 385.470 \\
\hline
\end{tabular}

sumber Hasi Perhitungan

Tabel 8. Kebutuhan Air Untuk Hidrant Umum $2018-2033$

\begin{tabular}{|c|c|c|r|}
\hline \multirow{2}{*}{ Tahun } & Jumlah Penduduk & $\begin{array}{c}\text { Standar } \\
\text { Pemakaian }\end{array}$ & Kebutuhan Air \\
\cline { 2 - 4 } & Terlayani (Jiwa) & (L/o/hari) & (L/hari) \\
\hline 2018 & 1230 & 30 & 36.900 \\
\hline 2023 & 416,1 & 30 & 12.483 \\
\hline 2028 & 0 & 30 & - \\
\hline 2033 & 0 & 30 & - \\
\hline
\end{tabular}

sumber Hasi Perhitungan

\subsection{Kebutuhan Air Non Domestik}

Kebutuhan air non domestik berdasarkan tata guna lahan sebagaimana tabel berikut,

Tabel 9. Tata Guna Lahan Fasilitas NonDomestik Daerah Pelayanan

\begin{tabular}{|c|c|c|c|c|}
\hline \multirow{2}{*}{ N0 } & \multicolumn{3}{|c|}{ Jenis Fasilitas } & \multicolumn{2}{c|}{ Keterangan } \\
\cline { 4 - 5 } & \multicolumn{2}{|c|}{} & $\begin{array}{c}\text { Jumlah } \\
\text { (Unit) }\end{array}$ & $\begin{array}{c}\text { jumlah } \\
\text { (jiwa) }\end{array}$ \\
\hline $\mathbf{1}$ & Fasilitas Pendidikan & TK & 1 & 81 \\
\hline & & SD & 2 & 480 \\
\hline & & SLTP & 2 & 263 \\
\hline & & SMA & 1 & 220 \\
\hline $\mathbf{2}$ & Fasilitas Peribadatan & Masjid & 1 & - \\
\hline & & Musholla & 3 & \\
\hline $\mathbf{3}$ & Fasilitas Kesehatan & Puskesmas & 1 & \\
\hline $\mathbf{5}$ & Fsilitas Umum & Koperasi & & - \\
\hline & & Perkantoran & 1 & - \\
\hline $\mathbf{7}$ & $\begin{array}{c}\text { Fasilitas Perdagangan } \\
\text { dan Jasa }\end{array}$ & Pelabuhan & 3 & - \\
\hline & & Pasar & 1 & - \\
\hline \multicolumn{2}{|l|}{ Sumber: Survey Lapangan } & & & \\
\hline
\end{tabular}

Tabel 10. Kebutuhan Air Non Domestik untuk Katagori V ( Desa ) 


\begin{tabular}{|l|c|l|}
\hline \multicolumn{1}{|c|}{ Sektor } & Nilai Kebutuhan & \multicolumn{1}{c|}{ Satuan } \\
\hline Sekolah & 10 & liter/murid/hari \\
\hline Mesjid & 3.000 & liter/hari \\
\hline Musholla & 2.000 & liter/hari \\
\hline Puskesmas & 1.200 & liter/pegawai/hari \\
\hline Kawasan industri & 10 & liter/hari \\
\hline Pasar & 12.000 & liter/Unit/hari \\
\hline
\end{tabular}

Sumber: Ditjen Cipta Karya DPU

\subsubsection{Fasilitas Pendidikan}

Rekapitulasi Proyeksi Kebutuhan Air Bersih Untuk Fasilitas Pendidikan disajikan dalam tabel berikut :

Tabel 11. Proyeksi Kebutuhan Air Bersih Untuk Fasilitas Pendidikan

\begin{tabular}{|c|c|c|c|c|c|c|c|c|c|c|}
\hline \multirow[t]{2}{*}{ No } & \multirow[t]{2}{*}{ Fasiltas } & $\begin{array}{l}\text { Standar } \\
\text { Kebuthan }\end{array}$ & 2018 & $\begin{array}{c}\text { Kebutuhan } \\
\text { Air }\end{array}$ & 2023 & $\begin{array}{c}\text { Kebutula } \\
\text { nAir }\end{array}$ & 2028 & $\begin{array}{c}\text { Kebuthala } \\
\text { nAir }\end{array}$ & 2033 & $\begin{array}{c}\text { Kebuth } \\
\text { anAir }\end{array}$ \\
\hline & & (LMrdhari & $(\mathrm{Mrd})$ & (L/deatik) & (Mrd) & (L/detik) & $(\mathrm{Mrd})$ & $(\mathrm{L} / \mathrm{det} \mathrm{d})$ & $(\mathrm{Mrd})$ & $(\mathrm{L} /$ detik) \\
\hline 1 & TK & 10 & 81 & 0,009375 & 84,75 & 0,00981 & 88,7 & 0,01026 & 92,8 & 0,010 \\
\hline 2 & SD & 10 & 480 & 0,055556 & 502,24 & 0,05813 & 526 & 0,06082 & 550 & 0,063 \\
\hline 3 & LTP & 10 & 263 & 0,03044 & 275,19 & 0,03185 & 288 & 0,03333 & 301 & 0,034 \\
\hline 4 & $\mathrm{TA}$ & 10 & 220 & 0,025463 & 230,19 & 0,02664 & 241 & 0,02788 & 252 & 0,0291 \\
\hline & Jomle & & & 0,120833 & & 0,12643 & & 0,13229 & & 0,138 \\
\hline
\end{tabular}

Sumber : Hasil Perhitungan

\subsubsection{Fasilitas Peribadatan}

Proyeksi kebutuhan air bersih untuk fasiltas peribadatan sebagaimana tabel berikut,

Tabel 12. Proyeksi Kebutuhan Air Bersih Untuk Fasilitas Peribadatan

\begin{tabular}{|c|c|c|c|c|c|c|c|c|c|}
\hline \multirow[t]{2}{*}{$\begin{array}{lll}\text { No } & \text { Fasilitas }\end{array}$} & \begin{tabular}{|l} 
Standar \\
Kebotuhan
\end{tabular} & 2018 & $\begin{array}{c}\text { Ketoutulan } \\
\text { Air }\end{array}$ & 2023 & $\begin{array}{l}\text { Kebotuthan } \\
\text { Air }\end{array}$ & 2028 & $\begin{array}{c}\text { Kebutuharar } \\
\text { Air }\end{array}$ & 2033 & $\begin{array}{c}\text { Kebutuhan } \\
\text { Air }\end{array}$ \\
\hline & \begin{tabular}{|l|l|} 
(Luithail \\
\end{tabular} & (Unit) & (Ldetik) & (Unit) & (Ldetik) & (Unit) & (Ldetik) & (Unit) & (Ldetik) \\
\hline \begin{tabular}{l|l}
1 & Masjid \\
\end{tabular} & 3000 & 1 & 0,034722 & 1,0463 & 0,06633 & 1,0948 & 0,03801 & 1,0948 & 0,03801 \\
\hline \begin{tabular}{l|l}
2 & Mushola \\
\end{tabular} & 2000 & 3 & 0,06944 & 3,139 & 0,07266 & 32845 & 0,07603 & 3,2845 & 0,07603 \\
\hline \multicolumn{2}{|c|}{ Jumlah } & 4 & 0,1042 & 4,1853 & 0,1090 & 43793 & 0,1140 & 4,3793 & 0,1140 \\
\hline
\end{tabular}

Sumber : Hasil Perhitungan

\subsubsection{Fasilitas Kesehatan}

Proyeksi kebutuhan air bersih untuk fasiltas kesehatan sebagaimana tabel berikut,

Tabel 13. Proyeksi Kebutuhan Air Bersih Untuk Fasilitas Kesehatan

\begin{tabular}{|c|c|c|c|c|c|c|c|c|c|c|}
\hline \multirow[t]{2}{*}{$\mathrm{No}$} & \multirow[t]{2}{*}{ Fasilitas } & lan noury & 18 & $\begin{array}{c}\text { Kebuthan } \\
\text { Air }\end{array}$ & 2023 & $\begin{array}{c}\text { Kebutuha } \\
\text { nAir }\end{array}$ & 2028 & $\begin{array}{c}\text { Kebotuha } \\
\text { nAir }\end{array}$ & 2033 & $\begin{array}{c}\text { Ketoutunn } \\
\text { Air }\end{array}$ \\
\hline & & (L/untheni) & Unit) & (L/detik) & (Uit) & (L/detk) & (Unit) & (L/detk) & (Unit) & $(\mathrm{L} /$ detik $)$ \\
\hline 1 & Puskesmas & 1200 & 1 & 0,013889 & 1,05 & 0,01453 & 1,09 & 0,01521 & 1,146 & 0,01591 \\
\hline & Jumb & & & 0,013889 & & 0,014532 & & 0,015206 & & 0,0159 \\
\hline
\end{tabular}

Sumber : Hasil Perhitungan

\subsubsection{Fasilitas Perdagangan dan Jasa}

Fasilitas Perdagangan dan Jasa yang terdapat di simpang gaung hanya yaitu Pasar Tradisional yan Terletak Dipusat Desa, dan Beberapa pelabuhan yg penumpang dan barang yaang melayani transportasi laut sungai simpang gaung.

Tabel 14. Proyeksi Kebutuhan Air Bersih Untuk Fasilitas Perdagangan dan Jasa

\begin{tabular}{|c|c|c|c|c|c|c|c|c|c|c|}
\hline No & Fasilitas & \begin{tabular}{|c|} 
Standar \\
Kebotithan \\
\end{tabular} & 20 & \begin{tabular}{|c|} 
Kebtudun \\
Air \\
\end{tabular} & 2023 & $\begin{array}{c}\text { Kebotula } \\
\text { nAir }\end{array}$ & 2028 & \begin{tabular}{|c} 
Kebatha \\
nAir
\end{tabular} & 2033 & $\begin{array}{c}\text { eboutla } \\
\text { Air }\end{array}$ \\
\hline & & (Lunithani) & (Unit) & (L/dedik) & (Unit) & $(\mathrm{L} / \mathrm{det})$ & (Unit) & (L/dedk) & (Unit) & (L/detik \\
\hline 1 & Pelabuhan & 1200 & 3 & 0,041667 & 3,14 & 0,04360 & 3,28 & 0,04562 & 3,437 & 0,04 \\
\hline 2 & Pasa & 12.000 & 1 & 0,138889 & 1,05 & 0,14532 & 1,09 & 0,15206 & 1,146 & 0,15910 \\
\hline \multicolumn{4}{|c|}{ Jumlah } & 0,180556 & & 0,188922 & & 0,197676 & & 006 \\
\hline
\end{tabular}

Sumber : Hasil Perhitungan

Hasil perhitungan Proyeksi Kebutuhan Air Bersih Untuk domestik dan non domestik disajikan dalam tabel berikut :

Tabel 15. Rekapitulasi kebutuhan Air Domestik dan non Domestik

\begin{tabular}{|c|c|c|c|c|c|}
\hline \multirow[t]{2}{*}{$\mathrm{N}_{0}$} & \multirow[t]{2}{*}{ Fasilitas } & \multicolumn{4}{|c|}{ Kebutuhan (L/detik) } \\
\hline & & 2018 & 2023 & 2028 & 2033 \\
\hline \multirow[t]{3}{*}{1} & Domestik & & & & \\
\hline & - Sambungan Rumah & 2,990 & 3,9009 & 4,398 & 4,461 \\
\hline & - Hidran Umum & 0,4271 & 0,14448 & & \\
\hline \multicolumn{2}{|c|}{ Jumlah (L/detik) } & 3,417 & 4,045 & 4,398 & 4,461 \\
\hline \multirow[t]{5}{*}{2} & Non Domestik & & & & \\
\hline & - Fasilitas Pendidikan & 0,1208 & 0,1264 & 0,1323 & 0,1384 \\
\hline & - Faslitias Perbadatan & 0,1042 & 0,1090 & 0,1140 & 0,1193 \\
\hline & - Fasilitas Kesehatan & 0,013889 & 0,014532 & 0,015206 & 0,015910 \\
\hline & - Fasilitas Perdagangan dar & 0,180556 & 0,188922 & 0,197676 & 0,206835 \\
\hline \multicolumn{2}{|c|}{ Jumlah (L/detik) } & 0,4194 & 0,4389 & 0,4592 & 0,4805 \\
\hline \multicolumn{2}{|c|}{ Jumlah Total (L/detik) } & 3,8361 & 4,4843 & 4,8571 & 4,9420 \\
\hline
\end{tabular}

Sumber : Hasil Perhitungan

\subsubsection{Kehilangan Air}

Besarnya kebutuhan air, perlu 
diperhitungkan juga besarnya kebocoran atau kehilangan air dari sistem. Besarnya kehilangan air diperkirakan sebesar 20\% dari kebutuhan total sampai akhir tahun perencanaan (sumber ; Dinas Pekerjaan Umum, 2004). Rekapitulasi Proyeksi Kebutuhan Air Bersih akibat kehilangan air disajikan dalam Tabel berikut,

Tabel 16. Kehilangan Air

\begin{tabular}{|c|c|c|c|}
\hline Tahun & $\begin{array}{c}\text { Q } \\
\text { (L/det) }\end{array}$ & $\begin{array}{c}\text { Kehilangan } \\
(\mathbf{\%})\end{array}$ & $\begin{array}{c}\text { Q } \\
\text { (L/det) }\end{array}$ \\
\hline 2018 & 3,8361 & 20 & 0,7672 \\
\hline 2023 & 4,4843 & 20 & 0,8969 \\
\hline 2028 & 4,8571 & 20 & 0,9714 \\
\hline 2033 & 4,9420 & 20 & 0,9884 \\
\hline
\end{tabular}

Sumber : Hasil Perhitungan

\subsubsection{Kebutuhan Air Total}

Besarnya kebutuhan air berdasarkan perhitungan proyeksi sampai akhir perencanaan adalah sebagai berikut

Tabel 17. Kebutuhan Air Total

\begin{tabular}{|r|r|r|r|r|}
\hline Tahun & $\begin{array}{c}\text { Q Domestik } \\
\text { (L/det) }\end{array}$ & $\begin{array}{c}\text { Q Non } \\
\text { Domestik } \\
\text { (L/det) }\end{array}$ & $\begin{array}{c}\text { Q Kehilangan } \\
\text { (L/det) }\end{array}$ & $\begin{array}{l}\text { Q Total } \\
\text { (L/det) }\end{array}$ \\
\hline 2018 & 3,417 & 0,4194 & 0,7672 & 4,603 \\
\hline 2023 & 4,045 & 0,4389 & 0,8969 & 5,381 \\
\hline 2028 & 4,398 & 0,4592 & 0,9714 & 5,829 \\
\hline 2033 & 4,461 & 0,4805 & 0,9884 & 5,930 \\
\hline
\end{tabular}

Sumber : Hasil Perhitungan

\subsubsection{Kapasitas Produksi}

Kapasitas dari bangunan pengolahan air dihitung berdsarkan pada faktor maksimum hari, dimana faktor maksimum hari (fmd) sebesar 1.20 (1.15- 1.20) (Sumber ; Dinas Pekerjaan Umum, 2002)

Total kebutuhan domestik dan non domestik sampai akhir masa perencanaan tahun 2033 adalah 5,930 L/dtk sehingga kapasitas produksi dapat dihitung sebagai berikut :

$$
\begin{aligned}
& \text { Qprod }=\text { Qtotal } \times \text { fmd } \\
& \text { Qprod }=5,930 \text { L/dtk } \times 1,20 \\
& \text { Qprod }=7,116 \text { L/dtk }
\end{aligned}
$$

\section{KESIMPULAN DAN SARAN}

\subsection{KESIMPULAN}

Berdasarakan hasil analisa proyeksi penduduk dan analisa kebutuhan air bersih desa simapang gaung kacamatan gaung didapatkan hasil sebagai berikut :

1. proyeksi penduduk desa simpang gaung kecamatan gaung didapatkan berdasarkan data penduduk 5 tahun terakhir, untuk mendapatkan proyeksi penduduk 10 tahun kedepan.
2. hasil proyeksi pendudk 10 tahun kedepan yaitu pada tahun 2028, dihitung dengan menggunakan tiga metode dengan hasil sebaggai berikut :

Hasil proyeksi penduduk pada tahun 2028

\begin{tabular}{|c|c|c|}
\hline Aritmatik & Geometrik & Eksponensial \\
\hline 4334 & 4258 & 4258 \\
\hline
\end{tabular}

3. Kapasitas air yang dibutuhkan masyarakat desa simapang gaung kacamatan gaung sampai tahun 2033 yaitu sekitar 4,9420 L/dtik, yang terdiri dari kebutuhan air domestik dan non domestik yang terbagi dalam rincian kebutuhan air sampai tahun 2033 sebagai berikut :
a. Penduduk
$=4,461 \mathrm{~L} / \mathrm{d}$
b. Fasilitas pendidikan $=0,1384 \mathrm{~L} / \mathrm{d}$
c. Fasilitas peribadatan $=0,1193 \mathrm{~L} / \mathrm{d}$
d. Fasilitas kesehatan $=0,0159 \mathrm{~L} / \mathrm{d}$
e. Perdagangan dan Niaga
$=0,2068 \mathrm{~L} / \mathrm{d}$

\subsection{SARAN}

Melihat karakteristik wilayah penelitian berupa kawasan permukiman Pedesaan yang dekat dengan lautan yang memiliki potensi sumber air permukaan dan tanah dalam yang asin, sehingga perlu kajian lebih mendalam terkait penentuan letak sumber air yang akan dimanfaatkan dalam peningkatan pelayanan distribusi air bersih.

\section{DAFTAR PUSTAKA}

[1] A.Soedradja S.Ir 1983. Mekanika Fluida dan Hidraulika. Penerbit Nova : Bandung

[2] Anonimous, 1990. Pedoman Teknis Penyediaan Air Bersih IKK Pedesaan. Direktorat Jendral Cipta Karya Departemen PU, Jakarta

[3] Kindler. J and Russell. CS, 1984. Modeling Water Demand. Acedemic Perss Inc, New York

[4] Muliakusumah, Sutarsih. 2000, Proyeksi Penduduk. Penerbit Erlangga : Jakarta

[5] Merle C. Potter, Ph.D, David C. Wiggert, Ph.D. 2008. Mekanika Fluida. Penerbit Erlangga : Ciracas - Jakarta

[6] Orianto.M.Ir.BSE, W.A. Pratikto.Ir.M. Sc. 1984. Mekanika Fluida I. Penerbit BPFE : Yogjakarta

[7] Raswari, 1987. Perencanaan dan Penggambaran Sistem Perpipaan, Universitas Indonesia : Jakarta

[8] Raden Mohamad Besari, 1978. Ilmu Teknik Pengairan. Pradnya Paramita.

[9] Ray K. Linsley, 1986. Teknik Sumber 
Daya Air Jilid 2 Edisi Ketiga. Erlangga, Jakarta

[10] Rip Weaper, 2000. Desain Pipa Proses Volume 1 \& 2. Universitas Indonesia, UI-Press

[11] O.F. Patty, 1995. Tenaga Air. Erlangga

[12] Soewarno, 1995, Hidrologi I. Penerbit Nova : Bandung

[13] Sowarno, 1990. Hidrologi. NOVA. Bandung

[14] Triatmadja, Radianta, 2009, Hidraulika. Penerbit Beta Offset : Yogyakarta

[15] Triatmodjo, Bambang, 1996, Hidrolika I. Penerbit Beta Offset : Yogyakarta

[16] Triatmodjo, Bambang, 2003, Hidrolika II. Penerbit Beta Offset : Yogyakarta

[17] Triatmadja, Radianata, 2007, Sistem Penyediaan Air Minum Perpipaan, DRAF, Yogyakarta

[18] Thomas Krist, 1991. Hidraulika Ringkas dan Jelas. Erlangga, Jakarta

SKRIPSI/TA

[1] Hendrawati Pamungkas, Skripsi "Evaluasi Debit Air Dan Diameter Pipa Distribusi Air Bersih Di Perumahan Kampung Nelayan Kelurahan Nelayan Indah Belawan", Jurusan Teknik Sipil, Universitas Sebelas Maret, Surakarta.

[2] Rivai Yuliana, Skripsi "Evaluasi Sistem Distribusi Dan Rencana Peningkatan Pelayanan Air Bersih", Gorontalo, 2006 